\title{
Kronik Venöz Yetmezliği Olan Bireylerde Manyetik Alan Tedavisinin Ödem, Eklem Hareket Açıklığı, Depresyon ve Yaşam Kalitesine Etkisi
}

\author{
Effects of Magnetic Field Therapy on Edema, Range of Joint \\ Motion, Depression, and Life Quality in Patients with Chronic \\ Venous Insufficiency
}

\begin{abstract}
Öz
Amaç: Bu çalışmanın amacı düşük frekanslı kesikli manyetik alan (KEMA) tedavisinin kronik venöz yetmezliği olan hastalarda ödem, yaşam kalitesi, depresyon ve eklem hareket açıklığına etkisini incelemektir Gereç ve Yöntemler. Bu çalışmaya kronik venöz yetmezlik tanısı almış, CEAP (klinik-etiyolojik-anatomik-patofızyolojik) sınıflamasına göre C3-C6 olan 55 hasta dahil edildi. Hastaların demografik bilgileri çalışma öncesinde toplandı ve analiz edildi. Klinik değerlendirmelerde ise Venöz Yetmezlikte Epidemiyolojik ve Ekonomik Çalışma-Yaşam Kalitesi Anketi (VEINES-QOL), Beck Depresyon Ölçeği (BDÖ), eklem hareket açıkığı (EHA) ve çevre ölçümleri kullanıldı. Hastalar tedavi $(n=21)$ ve kontrol grubu $(n=24)$ olarak rastgele sayı oluşturucu kullanılarak iki gruba ayrılı. Tüm testler çalışmanın başlangıcında ve bitişinde olmak üzere iki kez uygulandı. Illk değerlendirmenin ardından KEMA terapisi haftanın 5 günü 6 hafta boyunca uygulama grubuna uygulandı. Bireylere aynı zamanda kompresyon çorabı verilerek 6 hafta kullanmaları istendi. Kontrol grubu ise 6 hafta boyunca sadece kompresyon çorabı kullandı.

Bulgular. Her bir grubun ilk ölçüm, son ölçüm değerleri karşılaştıııldığında, tedavi grubunda etkilenen ekstremitede ayak bileği dorsifleksiyon ve plantar fleksiyon hareketlerinde ve depresyon ölçümlerinde anlamlı fark bulundu $(p<0,001 ; p=0,007 ; p<0,001)$. Çevre ölçümleri, depresyon ve yaşam kaliteleri bakımından gruplar karşılaştırıldığında depresyon değerlendirmesi ve ayak bileği (CB) ve ayak bileği üstündeki bölgenin (CB1) çevre ölçümlerinde anlamlı fark olduğu saptandı $(p<0,05)$.

Tartışma ve Sonuç: Bu çalışma düşük frekanslı KEMA tedavisi uygulamasının kronik venöz yetmezliği olan bireylerde eklem hareket açıkığını artırdığını, ödem ve depresyonu azalttığını gösterdi. Bu çalışma ülkemizde manyetik alan tedavisinin kronik venöz yetmezliğin diğer evrelerinde de kullanıldığı ilk çalışmadır. Uzun dönem takip edilen daha büyük bir örneklemle tekrarlanmasının literatüre katkı sağlayabileceği düşüncesindeyiz.
\end{abstract}

Anahtar Sözcükler. manyetik alan; ödem; yaşam kalitesi

\section{Abstract}

Aim: In this study, we aimed to investigate effects of low frequency pulsed electromagnetic field therapy (PEFT) therapy on edema, life quality, depression, and range of joint motion in patients with chronic venous insufficiency.

Materials and Methods: Fifty-five patients with chronic venous insufficiency who were at C3-C6 according to the clinical-etiological-anatomic-pathophysiological (CEAP) classification were included the study. The demographic data of the patients were obtained and analyzed before the study. Clinical evaluations tools included the Venous Insufficiency Epidemiological and Economic Study-Quality of Life Questionnaire (VEINES-QOL), the Beck Depression Inventory (BDI), and range of joint motion and circumferential measurements. The patients were divided into two groups using random number generator as treatment $(n=21)$ and control $(n=24)$ groups. All tests were performed at both the beginning and the end of the study. Following the initial assessment, LFAM therapy was administered to the treatment group for 5 days a week for 6 weeks. The individuals were asked to use compression stockings for 6 weeks at the same time. The control group used only compression stockings for 6 weeks.

Results: When the first and last measurements of the both groups were compared, there was a significant difference in the ankle dorsiflexion and plantar flexion and depression measurements $(p<0.001, p=$ $0.007, p<0.001)$. When the groups were compared in terms of circumferential measurements, depression, and life quality, a significant difference was found in depression evaluation and circumferential measurements of the ankle (CB) and the area above the ankle (CB1) $(p<0.05)$

Discussion and Conclusion: This study showed that low-frequency low-dose electromagnetic field (PEFT) therapy increases joint motion range and decreases edema and depression in individuals with chronic venous insufficiency. This is the first study in our country where magnetic field therapy has been used in other stages of chronic venous insufficiency. We believe that the repetition of the study on a larger sample with longer follow-up periods might contribute to the literature.

Keywords: magnetic field; edema; life quality
Özlem Çınar Özdemir ${ }^{1}$ Ramazan Kurul', Elif Duygu', M. Fatih Uysal', Yeşim Bakar', Ömer Osman Pala², Kemalettin Erdem ${ }^{3}$, Handan Ankaralı ${ }^{4}$

Abant İzzet Baysal Üniversitesi K.D. Fizik Tedavi ve Rehabilitasyon Yüksek Okulu, Bolu Türkiye

Gazi Üniversitesi Sağlık Bilimleri Fakültesi Fizyoterapi ve Rehabilitasyon Bölümü, Ankara Türkiye

Abant İzet Baysal Üniversitesi Tıp Fakültesi Hastanesi Kalp ve Damar Cerrahisi AD, Bolu Türkiye

4 İstanbul Medeniyet Üniversitesi Tıp Fakültesi Biyoistatistik ve Tıbbi Bilişim AD, istanbul Türkiye

Geliş Tarihi /Received : 30.03.2017 Kabul Tarihi /Accepted: 18.04.2017

DOI: 10.21673/anadoluklin.303034

Sorumlu Yazar/Corresponding Author Yard. Doç. Dr. Özlem Çınar Özdemir Abant İzzet Baysal Üniversitesi

K. D. Fizik Tedavi ve Rehabilitasyon Yüksek Okulu Gölköy Kampüsü Bolu E-mail: ozlemcinar314@hotmail.com 


\section{GíRiş}

Kronik venöz yetmezlik (KVY) alt ekstremitelerde venöz sistemi etkileyen, kramp, bacaklarda huzursuzluk, ödem, ağrı ve deri değişiklikleri gibi çeşitli semptomları içeren bir hastalıktır. Yetişkinlerde KVY görülme olasılığ $\%$ 5-30 olarak tahmin edilmektedir $(1,2)$. KVY nedeniyle ödem, hiperpigmentasyon, egzama gibi kronik deri değişiklikleri de görülmektedir (3).

Alt ekstremite venöz sistemi derin, yüzeyel ve perforan venöz sistem olarak incelenir. Bu sistemlerde gelişen çeşitli patolojiler sonucunda venöz basınç yükselir ve bu durum tüm alt ekstremiteyi etkiler. $\mathrm{Bu}$ patolojileri kapak yetersizliği, venöz obstrüksiyon veya kalf kas pompasının yeterli çalışmaması oluşturur (1). Kalf kas pompası alt ekstremiteden kalbe kanın dönüşünde temel mekanizmadır. Ayak bileği eklemi kalf kas pompasının esas komponentidir, bu nedenle ayak bileği dorsifleksiyon ve plantar fleksiyon hareketleri kalf kas pompasının etkili fonksiyonu için temeldir (3). Limitli ayak bileğinin KVY'li hastalarda ödem formasyonunu ve venöz reflü şiddetini artırdığı bilinmektedir (4).

Mikrosirkülasyon, arteriyoller, kapillerler ve venüller gibi mikrodamar yapılarındaki kan akımını ifade eder. Vücut dokularının ve organlarının beslenmesi ile doğrudan ilişkilidir. Dokunun metabolik ihtiyacına göre değişiklik gösterir ve lokal regülatör mekanizmalarla kan akımını ve kan basıncını stabilize eder (5). Mikrosirkülasyon sadece küçük damarları etkilemekle kalmaz, damarların ilişkide bulunduğu hücresel ve plazmatik komponentler de etkilenir. Kan akımındaki artışla birlikte transkapiller sıvı alışverişi ve lenfatik akım da $\operatorname{artar}(6)$.

KVY'de fizyoterapi uygulamaları olarak kompleks boşaltıcı fizyoterapi (KBF), pnömatik kompresyon, kompresyon çorapları, venöz egzersiz programları, hasta eğitimi, biyomekanik stimülasyon terapi, PNF gevşeme teknikleri, hidroterapi ve manyetik alan tedavi yöntemleri kullanılmaktadır $(7,8)$. Kullanılan manyetik alan tedavisinin kökleri geçmişe dayanmaktadır. Antik dönemde Yunan, Çin, Japonya ve Avrupa'da manyetik maddelerin günlük yaşamda çeşitli uygulamalar esnasında farklı amaçlarla kullanıldığı bilinmektedir. Günümüzde manyetik alan tedavi uygulamalarının temellerinin ise İsviçreli bilim insanı Paracelcus'un 500 yıl önce, hastalıkları tedavi etmek için mıknatısı kullanmasıyla atılmış olduğu söylenebilir. Son yıllarda özellikle tıp alanında tedavi amaçlı elektromanyetik alan kullanımı, çeşitli yöntemlerle yaygınlaşmaya başlamıştır (9).

Tüm maddeler ve canllların hücresel düzeyde elektriksel yükler taşıdığı ve bu yüklerin akım oluşturabileceği göz önünde bulundurulduğunda, zayıf ya da güçlü bir manyetik alan özeliğinin tüm canlılarda bulunabileceği düşünülmektedir. İnsan vücudu bünyesinde bulundurduğu biyoelektrik yüklerin hareketi sayesinde aynı zamanda manyetik alana da sahiptir. Oluşan bu manyetik alan vücutta biyoelektrik oluşturan herhangi bir yapıda bulunabilir. Bu nedenle insan için hayati öneme sahip kalp, beyin, kas ve sinir gibi organlarda da manyetik alan mevcuttur ve vücut içerisinde hücresel düzeyde haberleşmede önemli role sahip olan manyetik alan sinyalleri birbiriyle uyum içinde bulunur (10).

Tedavide elektromanyetik alan uygulamaları vücudun hastalıklara vermiş olduğu doğal iyileşme sürecini ortaya çıkarmak için kullanılır. Fizyolojik anlamda vücuttaki metabolik olayların pek çoğu hücresel düzeyde ortaya çıan elektriksel yükler ve bu yüklerden kaynaklanan mikro düzeyde elektriksel akımlar ile gerçekleşir. Hücresel düzeyde ortaya çıkan bu akımlar aynı zamanda hücreler arası iletişimde, vücut fizyolojik metabolizmasının düzenlenmesinde oldukça önemli role sahiptir (9)

KEMA tedavisinin ağrı, kırık kaynama gecikmesi, Parkinson vb. hastalıklarda kullanıldığı bilinmektedir ve tedavinin faydalarının statik ve zamanla değișen manyetik alanlarla elde edilebildiği bildirilmektedir (11).

Elektromanyetik alanların, lokal doku oksijen basinçlarında yükselmelere ve doku ödeminde azalmalara, bununla birlikte doku perfüzyonunda değişikliklere sebep olduğu klinik çalışmalar ile gösterilmiştir. $\mathrm{Bu}$ dolaşım değişikliklerinin yapılan hayvan deneylerinde, sağlıklı insanlarda ve periferik damar hastalığ bulunanlarda tutarlı olduğu belirtilmiştir (12-15).

Yaşam kalitesinde azalma KVY'de görülen ağrı, fiziksel fonksiyon ve mobilite kaybına bağlı gelişmektedir (16). KVY'li kişilerin yaşam kalitelerinin daha kötü olduğu araştırmalarda bildirilmiştir $(17,18)$. Venöz hastalıklar yüksek prevalansa sahiptir. Ancak bu hastalık grubunda hastalığın yaşam kalitesi, günlük 
Tablo 1. Bireylerin demografik özellikleri

\begin{tabular}{|c|c|c|c|}
\hline & $\begin{array}{l}\text { Tedavi grubu } \\
\qquad \begin{array}{c}\mathbf{n}=\mathbf{2 1} \\
\mathrm{X} \pm \mathrm{SS}\end{array}\end{array}$ & $\begin{array}{c}\text { Kontrol grubu } \\
\qquad \begin{array}{c}\mathbf{n}=\mathbf{2 4} \\
\mathrm{X} \pm \mathrm{SS}\end{array}\end{array}$ & $\mathbf{p}$ \\
\hline Yaş (yıl) & $52,14 \pm 15,41$ & $54,62 \pm 12,54$ & 0,561 \\
\hline $\operatorname{Boy}(\mathrm{cm})$ & $167 \pm 11,20$ & $162 \pm 7,25$ & 0,082 \\
\hline Kilo (kg) & $84,28 \pm 16,47$ & $80,43 \pm 14,90$ & 0,415 \\
\hline VKİ $\left(\mathbf{k g} / \mathbf{m}^{2}\right)$ & $30,96 \pm 5,58$ & $31,07 \pm 6,29$ & 0,956 \\
\hline
\end{tabular}

VKİ: vücut kitle indeksi; cm: santimetre; kg: kilogram; n: birey sayısi; $\mathrm{X} \pm$ SS: ortalama \pm standart sapma; $\mathrm{p}<0,05$

fonksiyonlar ve depresyon üzerindeki etkisini inceleyen çalışmalar sinırlıdır (18-21).

$\mathrm{Bu}$ çalışmanın amacı düşük frekanslı KEMA tedavisinin KVY tanılı hastalarda ödem, yaşam kalitesi, depresyon ve EHA üzerine etkisini incelemektir.

\section{GEREÇ VE YÖNTEMLER}

\section{Katılımcılar}

Bu çalışmaya KVY tanısı almış 95 hasta dahil edildi. Dahil edilme kriterlerini karşılayan CEAP (kliniketiyolojik-anatomik-patofizyolojik) sinıflamasina göre C3-C6 olan 55 hasta çalışmaya dahil edildi. Dahil edilme kriteri Doppler ultrasonografi ile KVY tanısı almış olmak, dışlanma kriterleri ise derin ven trombozu, akut venöz hastalıklar, renal bozukluklar, malign prognoz, bakteri veya mantar kaynaklı enfeksiyonlar ve bölgede geçirilmiş cerrahi öyküsü olarak belirlendi. Hastalardan bilgilendirilmiş onam çalışmaya başlamadan alındı. Çalışma etik olarak Düzce Üniversitesi Tip Fakültesi Klinik Araştırmalar Etik Kurulu tarafından onaylandi (2013/431).

Denek sayısı G-Power ${ }^{\star}$ kullanılarak Piatkowski’nin $(22,23)$ çalışması örnek alınarak anlamlılık ve istatiksel gücü sırası ile $\% 5$ ve $\% 80$ olarak hesaplandı ve yapılan analizde her grup için en az 20 birey alınması gerektiği tespit edildi.

Dahil edilme kriterlerini sağlayan hastalar tedavi $(n=21)$ ve kontrol grubu $(n=24)$ olarak rastgele say1 oluşturucu kullanılarak iki gruba ayrıldı. Çalışma esnasında kişisel nedenlerden dolayı tedavi grubundan 1 kişi, kontrol grubundan ise 2 kişi olmak üzere toplam 3 hasta çalışmadan ayrıldı. Çalışmanın başlangıcından itibaren değerlendirilen ve analiz edilen bireyler akış diyagramında belirtildi (Şekil 1).

\section{Klinik Değerlendirme}

Hastaların demografik bilgileri çalışma öncesinde toplandı ve analiz edildi. Klinik değerlendirmelerde ise Venöz Yetmezlikte Epidemiyolojik ve Ekonomik Çalışma-Yaşam Kalitesi Anketi (VEINES-QOL), Beck Depresyon Ölçeği (BDÖ), eklem hareket açıklığı (EHA) ve çevre ölçümleri kullanıldı. Tüm testler çalışmanın başlangıcında ve bitişinde olmak üzere iki kez uygulandi.

VEINES-QOL hastalığa özgü yaşam kalitesi ölçeği olarak kullanıldı. Ölçek toplam 26 sorudan oluşmaktadır. KVY semptomları, KVY’ye bağlı günlük yaşam aktivite kısıtlllığı, psikolojik etkileri, son bir yıl içinde etkilenen bacakta olan değişiklikler ve bacaktaki problemin gün içerisinde en yoğun olduğu zaman olarak 5 alt basamağa ayrılır. Her soru için skor 0-6 arasında değişmektedir. Yüksek skorlar daha iyi sonuç olduğunu göstermektedir (24).

BDÖ kişinin kendi bildirimine dayanan depresyonun karakteristiğini ve semptomlarını ölçmeyi amaçlayan 21 soruluk bir ölçektir. Her soru için alınabilecek skor 0-3 arasında değişmektedir. Yüksek skorlar kliniğin kötü olduğunu göstermektedir (25).

Bireylerde ayak bileği dorsifleksiyon ve plantar fleksiyon gonyometre ile değerlendirildi. Ölçümler sırtüstü pozisyonda alındı. Pivot noktası olarak lateral malleol kullanıldı. Eklem hareketleri derece cinsinden kaydedildi (26).

Bireylerin alt ekstremite ödem miktarlarını belirlemek amacıyla çevre ölçümleri mezura ile alındı. Ölçümlerin daha standart olması amacıyla çevre ölçümleri yapılırken Leg-O-Meter ölçüm aleti kullanıldı. Cihaz ayağın ve bacağın yerleştirildiği tahta bir düzlemden oluşmaktadır. Bu düzlem üzerinde santimetre cinsinden aralıklar mevcuttur ve bu durum çevre ölçümlerinin hep aynı noktadan yapılmasına olanak 
Tablo 2. Bireylerin venöz semptomları ve tanımlayıcı özelliklerinin gruplara göre dağılımı

\begin{tabular}{|c|c|c|c|c|c|}
\hline & & \multicolumn{2}{|c|}{ Tedavi grubu } & \multicolumn{2}{|c|}{ Kontrol grubu } \\
\hline & & $\mathbf{n}$ & $\%$ & $\mathbf{n}$ & $\%$ \\
\hline \multirow[t]{2}{*}{ Sigara kullanımı } & Var & 3 & 14,3 & 8 & 33,3 \\
\hline & Yok & 18 & 85,7 & 16 & 66,7 \\
\hline \multirow[t]{2}{*}{ Ağrı gerginlik } & Var & 16 & 76,2 & 20 & 83,3 \\
\hline & Yok & 5 & 23,8 & 4 & 16,7 \\
\hline \multirow[t]{2}{*}{ Varikoz ven } & Var & 12 & 57,1 & 16 & 66,7 \\
\hline & Yok & 9 & 42,9 & 8 & 33,3 \\
\hline \multirow[t]{2}{*}{ Bacak yorgunluğu } & Var & 18 & 85,7 & 21 & 87,5 \\
\hline & Yok & 3 & 14,3 & 3 & 12,5 \\
\hline \multirow[t]{2}{*}{ Kronik deri değişikliği } & Var & 9 & 42,9 & 5 & 20,8 \\
\hline & Yok & 12 & 57,1 & 19 & 79,2 \\
\hline \multirow[t]{2}{*}{ Telenjiektazi } & Var & 12 & 57,1 & 11 & 45,8 \\
\hline & Yok & 9 & 42,9 & 13 & 54,2 \\
\hline \multirow[t]{2}{*}{ Pigmentasyon } & Var & 4 & 19 & 6 & 25 \\
\hline & Yok & 17 & 81 & 18 & 75 \\
\hline
\end{tabular}

$\%$ : yüzde; n: birey sayısı

verir. Leg-O-Meter, alt ekstremite venöz hastalığı olan kişilerde kullanılan, klinik bulguların objektif olarak değerlendirilip diğer bacakla karşılaştırılabileceği bir ölçüm sağlayan, standardize bir ölçüm aracıdır (27). Ölçüm sırasında hastanın bacă̆ 1 Leg-O-Meter üzerine yerleştirildi ve mezura ile bacak çevre ölçümleri yapıldı. Çevre ölçümlerinde hassaslık derecesi $0,1 \mathrm{~cm}$ olan bükülebilir, elastik olmayan, $7 \mathrm{~mm}$ genişliğinde standart bir mezura kullanıldı. Mezuranın "0" (sıfır) ucu sol elde diğer ucu sağ elde olmak üzere ölçüm alınacak bölgeye sarılarak 0 (sıfır) noktasının üzerine gelen rakam not edildi. Ölçüm yapilırken mezuranın 0 (sıfır) noktası ile ölçüm sayısının üst üste değil, yan yana gelmesine dikkat edildi. Her ölçümde standardizasyonu sağlamak amacıyla hasta sırtüstü yatma pozisyonundayken ölçüm yapıldı. Ölçümler metatars başı hizası (CA), topuk-bilek (CY), bileğin en ince yeri (CB), gastroknemiyus kas gövdesinin başlangıcı (CB1), gastroknemiyus ortası (CC), fibula başı hizası (CD) ve diz orta noktası (CE) olmak üzere yedi noktadan yapildı.

\section{Uygulama}

Yanlılığın önlenmesi için hastalar hangi gruba dahil edildiklerini bilmeksizin uygulamaya alınd.
Aynı zamanda veri analizi çalışma grupları gizlenerek üçüncü bir analiste yaptırıldı.

İlk değerlendirmenin ardından düşük frekanslı KEMA terapisi haftanın 5 günü 6 hafta boyunca biyoelektro-manyetik-enerji-regülasyon (BEMER) cihazı kullanılarak tedavi grubuna uygulandı. Başlangıç dozu olarak $30 \mu \mathrm{T}$ ile başlanıp her hafta $30 \mu \mathrm{T}$ artırılarak $120 \mu \mathrm{T}$ seviyesine kadar çıkıldı. Uygulama 6 hafta boyunca her gün 8 dakika yapıldı. Uygulama esnasında herhangi bir yan etki gözlenmedi. Bireylere aynı zamanda kompresyon çorabı verilerek 6 hafta kullanmaları istendi. Kontrol grubu ise 6 hafta boyunca sadece kompresyon çorabı kullandı ve başka bir tedavi almad. Hastalar çorabı kullanma konusunda bilgilendirildi. Yataktan kalkmadan önce çorabı giymeleri, akşam yatana kadar çıkarmamaları ve gece uyurken kullanmamaları hususunda uyarıldı. Tedavide Jobst marka, ikinci sınıf basınç seviyesine sahip (23-32 mmHg) diz altı kompresyon çorabı kullanıldı. Çalışma süresince hem tedavi grubundaki hem de kontrol grubundaki hastalardan ayak bileği pompası egzersizini ( 3 set 10 tekrarlı) ve günlük 30 dakikalık yürüme egzersizlerini yapmaları istendi. 
Tablo 4. Yaşam kalitesi, depresyon ve çevre ölçüm farklarının gruplar arası karşılaştııılması

\begin{tabular}{cccc}
\hline & Tedavi grubu & Kontrol grubu & $\mathrm{p}$ \\
& $\mathrm{n}=21$ & $\mathrm{n}=24$ \\
$\mathrm{X} \pm \mathrm{SS}$ & $1,79 \pm 11,74$ & 0,469 \\
\hline VEINES-QOL & $6,10 \pm 25,95$ & $0,16 \pm 7,16$ & $\mathbf{0 , 0 0 2}$ \\
\hline BDÖ & $7,55 \pm 7,98$ & 0,066 \\
\hline $\mathbf{c A}(\mathbf{c m})$ & $0,93 \pm 3,03$ & $0,69 \pm 2,65$ & 0,543 \\
\hline $\mathbf{c Y}(\mathbf{c m})$ & $1,06 \pm 3,61$ & $\mathbf{1 , 7 7 \pm 4 , 0 7}$ & $\mathbf{0 , 0 2 6}$ \\
\hline $\mathbf{c B}(\mathbf{c m})$ & $3,41 \pm 7,43$ & $0,67 \pm 2,91$ & $\mathbf{0 , 0 1 6}$ \\
\hline $\mathbf{c B 1}(\mathbf{c m})$ & $5,30 \pm 7,43$ & $0,79 \pm 3,52$ & 0,873 \\
\hline $\mathbf{c C}(\mathbf{c m})$ & $0,84 \pm 1,11$ & $0,78 \pm 1,20$ & 0,095 \\
\hline $\mathbf{c D}(\mathbf{c m})$ & $1,15 \pm 2,23$ & $0,07 \pm 2,55$ & 0,190
\end{tabular}

p $<0,05$ independent $t$-testi; VEINES-QOL: Venöz Yetmezlikte Epidemiyolojik ve Ekonomik Çalışma-Yaşam Kalitesi Anketi; BDÖ: Beck Depresyon Ölçeği; $\mathrm{n}$ : birey sayısı; $\mathrm{X} \pm \mathrm{SS}$ : ortalama \pm standart sapma; cA: metatars başı hizası; cY: topuk-bilek; cB: bileğin en ince yeri; cB1: gastroknemiyus kas gövdesinin başlangıc1; cC: gastroknemiyus ortası; cD: fibula başı hizası; cE: diz orta noktası; cm: santimetre

\section{İstatistiksel Analiz}

Çalışmanın sayısal değişkenleri ortalama standart sapma (X土SS), sayı ve yüzde olarak gösterildi. İlgili sayısal değişkenlerin ortalamaları bakımından cinsiyetlerin karşılaştırılmasında ise independent-samples $t$-testi kullanıldı. Ayrıca her bir grupta egzersiz öncesi ve egzersiz sonrası arasındaki farkların anlamlı olup olmadığı bağımlı iki grubun karşılaştırılmasında kullanılan paired $t$-testi ile değerlendirildi. İstatistik anlamlılık düzeyi olarak $\% 5$ alındı ve test sonucunda hesaplanan p değeri \%5’ten küçük ise sonuç istatistiksel olarak anlamlı kabul edildi. Verilerin analizi için SPSS (v. 16.0) istatistik programı kullanıldı.

\section{BULGULAR}

Çalışmaya yaş ortalaması 52,14 15,41 yıl ve $54,62 \pm 12,54$ yıl olan KVY tanısı almış 55 birey dahil edildi. Bireylerin yaş, boy, kilo ve vücut kitle indeksi değerleri karşılaştırıldığında gruplar arasında fark olmadığı görüldü (Tablo 1).

Çalışmaya dahil edilen manyetik alan grubundaki bireylerin \%76,2'sinde ağrı-gerginlik, \%85,7'sinde bacak yorgunluğu, 57,1'inde telenjiektazi mevcuttu. Kontrol grubunda ise bireylerin \%83,3'ünde ağr1-gerginlik, $\% 87,5$ 'inde bacak yorgunluğu, $\% 45,8$ 'inde ise telenjiektazi bulguları gözlendi (Tablo 2).

Her bir grubun ilk ölçüm, son ölçüm değerleri kar- şlaştırıldığında, tedavi grubunda etkilenen ekstremitede ayak bileği dorsifleksiyon ve plantar fleksiyon hareketlerinde ve depresyon ölçümlerinde anlamlı fark bulundu ( $\mathrm{p}<0,001 ; \mathrm{p}=0,007 ; \mathrm{p}<0,001)$. Tedavi grubunun ilk ölçüm son ölçüm değerleri karşılaştırıldığında etkilenmeyen ekstremitenin dorsifleksiyon ve plantar fleksiyon hareketlerinde istatistiksel olarak anlaml fark görülmedi ( $>>0,05)$. Kontrol grubunda ise ilk ölçüm son ölçüm karşılaştırıldığında hiçbir parametrede anlamlı fark görülmedi ( $>0,05)$ (Tablo 3 ).

Çevre ölçümleri, depresyon ve yaşam kaliteleri değerleri bakımından tedavi grubu ve kontrol grubu karşılaştırıldığında depresyon değerlendirmesi ve ayak bileği (CB) ve ayak bileği üstündeki bölgenin (CB1) çevre ölçümlerinde anlamlı fark olduğu saptandı $(\mathrm{p}=0,002 ; \mathrm{p}=0,026 ; \mathrm{p}=0,016)$. Gruplar karşılaştırıldığında yaşam kalitesi değerleri, metatars başı hizası (CA), topuk-bilek (CY), gastroknemiyus ortası (CC), fibula başı hizası (CD), diz orta noktası (CE) bölgesinden yapılan çevre ölçüm değerlerinde anlamlı fark olmadığı bulundu ( $\mathrm{p}>0,05)$ (Tablo 4).

\section{TARTIŞMA}

Bu çalışma düşük seviye düşük doz KEMA tedavisi uygulamasının KVY'li bireylerde EHA'yı artırdığını, ödem ve depresyonu azalttığını gösterdi. 
KVY'de mikrosirkülasyon etkilenir. Israrlı ambulatuar venöz hipertansiyon sonucu cildin bozulan dolaşımı venöz egzamadan ülsere kadar çeșitli patolojilerin açığa çıkmasına sebep olur. Bunun yanı sıra kapillerler çevresindeki fibrin cuff oluşumu da mikrosirkülasyonu olumsuz etkiler. KVY'deki mikrosirkülasyondaki bozulma lipodermatoskleroz açığa çıkmadan çok daha önce meydana gelmektedir (28). Bu yüzden mikrosirkülasyon bozuklukları CEAP C3'ten itibaren gözle görülmeye başlamaktadır. Çalışmamıza da C3-6 arasinda sinıflandırılan hastalar alındı. Widmer'in sinıflamasına göre KVY şiddeti arttıkça dokudaki kapillerler sayısı azalmaktadır (28).

Manyetik alana maruz kalan doku veya kan damarlarındaki değişimleri inceleyen çalışma sayısı gittikçe artmaktadır (5). Manyetik alanın çeşitli vücut sistemleri üzerine olumlu etkileri literatürde bildirilmiştir Manyetik alan uygulaması analjezi sağlamada $(29,30)$ kırıkların hızlı iyileşmesinde, kartilaj tamirinde $(31,32)$, sinir rejenerasyonunun hızını artırmada etkili olabilmektedir (5). Kronik yaralarda (nöropatik, dekübit vb.), kas iskelet sistemi yaralanmalarında, kanser tedavisinde, nörolojik bozukluklarda düșük frekanslı KEMA tedavisi kullanımı bildirilmiştir (33). Devamlı manyetik alan uygulamalarına göre KEMA'nın önemli avantajı kesikli olmasından dolayı, devamlı manyetik alanın yarattığı ısıya bağlı doku hasarına karşı koruma sağlamasıdır (34).

Vazomosyon dokuya giden kan miktarını belirlemede esansiyeldir. Prekapiller arteriyoller ve postkapiller venüllerdeki vazomosyon normal şartlar altında dakikada 3-5'tir. Artan yaş ve hastalık şiddetiyle vazomosyon azalır. Prekapiller arteriyol ve postkapiller venüllerde 10 dakikada 1 vazomosyona kadar düşer. Yetersiz kan akımına bağlı olarak doku hasarı meydana gelir (35). Nispeten büyük damarlar reseptör içerdiğinden santral, hümoral ve nöral kontrol altındadır Küçük damarlardaki vazomosyon sayısı daha fazla ve otoritmiktir, düzenleme için reseptör içermez. Bu yüzden nispeten büyük damarlardaki gibi ilaç benzeri kimyasal enerji transferi ile uyarımı mümkün değildir. Dokulardaki mikrosirkülasyonun en önemli lokal düzenleyicisi spontan otoritmik vazomosyondur. $\mathrm{Bu}$ damarlardaki vazomosyon EMA gibi fiziksel enerjinin transferinden etkilenir (6). BEMER vücudun kendi regülatör mekanizmasını ve vazomosyonu stimüle eden fiziksel bir tedavi metodudur. Artan vazomosyonla birlikte kapiller ağdan venüllere drenaj belirgin şekilde artar (6). Hastaların yaşam kalitesi artar ve ağrısı azalir. Bunun sebebi artan venöz, lenfatik drenaj ve doku beslenmesinin venöz semptomların hafiflemesini sağlaması olabilir. Bununla birlikte düşük frekanslı düşük yoğunlukta KEMA tedavisinin potansiyel yan etkisi olmadan antienflamatuvar etkisi olabileceği literatürde belirtilmiştir (36).

Ayak bileği hareketleri gastroknemiyus kasının aktivitesi ile venöz kanın kalbe geri dönüşü için önemlidir. Ayak bileği hareketinin azalması ödemi artırdığ gibi ödemin azalması ile normal eklem hareketinde artış görülmektedir $(3,37)$. Ayak bileği limitasyonu KYV olan hastalarda ödem oluşmasını ve devamlı geri kaçışı artırmaktadır. Zamanla ödemde biriken fibrotik dokular ise ayak bileğinde hareket kısıtllılı̆̆ına yol açar. İnaktiviteye bağlı kalf kas pompası bozulur ve kanın geri dönüşü azalarak ödemde ve KVY semptomlarında artış görülür (4). Kas pompasının aktivasyonu için yürüme veya aktif kas kontraksiyonuna ek olarak dorsifleksiyon hareketinin en az 90 derece olması gerektiği bildirilmiștir (38). Çalıșmamızda eklem hareket açıklığ 1 değerlendirildiğinde etkilenen tarafta manyetik alan uygulaması sonrasinda plantar fleksiyon ve dorsifleksiyon değerlerinde tedavi grubu lehine anlaml değişim bulunmuştur. Klyscz ve Yang (39) yaptıkları çalışmalarda egzersizin kas pompası üzerinde olumlu etkisi olduğunu göstermişlerdir. Çalışmamızda her iki grup kompresyon çorabı kullandığı halde EHA'daki anlamlı artışın sadece tedavi grubunda görülmesi bu değişimin manyetik alan tedavisinin mikrosirkülasyonu artırıcı ve özellikle ayak bileği çevresinde ödemi azaltıcı etkisinden kaynaklandığını düşündürmektedir. Ayrıca çevre ölçümlerinde ayak bileği çevre ölçümü (CB) ve ayak bileği üstündeki gastroknemiyus kasının başlangıç bölgesinde (CB1) her iki grup arasında anlamlı fark bulundu. Aynı zamanda diğer bölgelerde de anlamlı fark görülmese de çevre ölçümlerinin ortalama değerlerinde azalma gözlenmiştir. Bu sonuçlar ayak bileğindeki ödem miktarının azalmasının ayak bileği normal eklem hareketinde de artış sağladığını gösterdi.

Kapiller hipertansiyon, kapiller filtrasyon ve protein permeabilitesinin artışı ve azalmış lenfatik rezorpsiyonun bir kombinasyonu olarak sonuçlanan bacak 


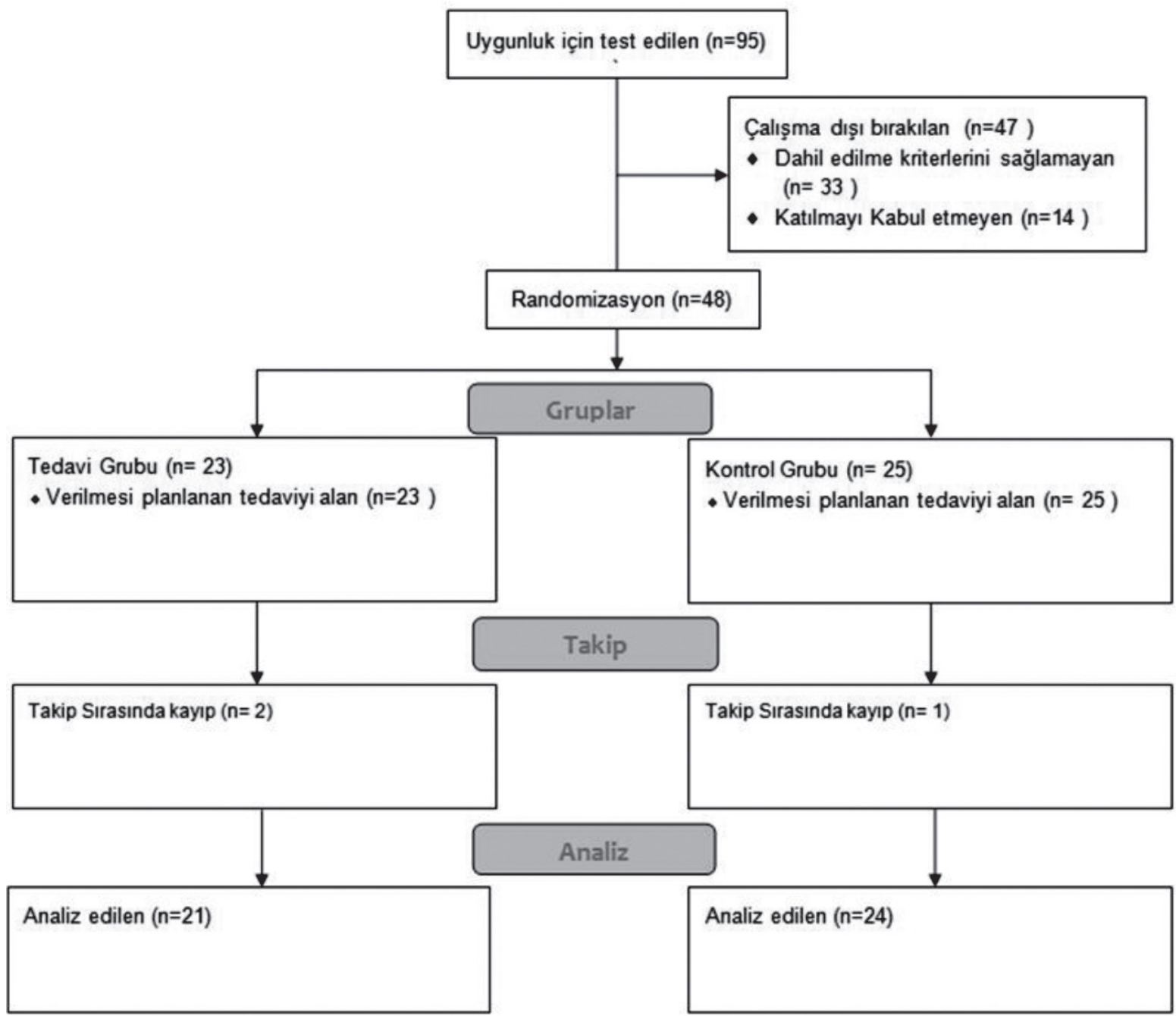

Şekil 1. Çalışmanın akış diyagramı

ödemi KVY'de en yaygin semptomdur (40). KVY'de dekompansasyonun erken işareti olan ödem, CEAP klinik sınıflamasına göre C3 olarak sınıflandırılmıştır. Bacak ödemini değerlendirmek için çeşitli yöntemler kullanılır. En yaygın olanı mezura ya da daha ayrıntılı bir biçimde Leg-O-Meter ile yapılan bacak çevre ölçümleridir. Diğer yöntemler ise volümetrik ölçümler, bilgisayarlı volüm ölçüm sistemleri ve biyoelektrik impedanstır (41). Bu yöntemler ulaşılabilir objektif ölçümler olmasına rağmen, yüksek fiyatları nedeniyle klinik pratikte rutin olarak kullanılmazlar (27). Çalışmamızda da çevre ölçümlerinin standart olarak hep aynı noktadan ölçülebilmesini sağlamak için Leg-OMeter cihazı kullanıldı.
KVY, semptomların ilerlemesi ile birlikte hastanın yaşam kalitesini etkileyen kronik bir hastalıktır (42). KVY'li kişilerin yaşam kalitelerinin daha kötü olduğu araştırmalarda bildirilmiştir $(17,18)$. Bu nedenle hastalığın etkisini belirlemek amacıyla uygulanan yaşam kalitesi ölçümleri problemin değerlendirmesinde önemlidir. Andreozzi ve ark. (21) yaşam kalitelerini inceledikleri çalışmalarında, CEAP 3. evre KVY'nin diabetus mellitus ve karsinoma ile aynı seviyede olduğunu, evre 4 KVY'nin karsinomadan ve kronik obstrüktif pulmoner hastalıktan daha kötü olduğunu ve evre 5-6 KVY'nin kalp yetmezliğine benzer olduğunu belirtmişlerdir (43).

KVY'ye özel yaşam kalitesi anketi olan VEINESQoL, hastanın psikolojik, sosyal ve fonksiyonel yeter- 
liliklerini değerlendiren bir ankettir (44). KVY olan hastalar üzerinde yapılan geniş çaplı bir araştırmada evrelere göre hastalar ayrılmış ve hastaların günlük yaşam aktivitelerinin hastalık nedeniyle nasıl değiştiği vurgulanarak hastalığa spesifik anket kullanımı önerilmiştir (43). Çalışmamızda tedavi grubunda hastalığa özgü yaşam kalitesinde artış olmasına rağmen kontrol grubu ile karşılaştırıldığında istatistiksel fark bulunmamıştır. Kontrol grubunda ise tedavi sonrasında hastalığa özgü yaşam kalitesinde anlamlı bir fark görülmemiştir. Bu sonuçlar manyetik alan uygulamasının yaşam kalitesi üzerine olumlu etkisi olduğunu göstermektedir.

KYV'de depresyon düzeyini belirlemek için BDÖ daha önce yapılan çalışmalarda kullanılmıştır. $\mathrm{Bu}$ hastalarda çeşitli derecelerde depresyon varlığı gösterilmiş, genel depresyon varlığı ise \%59 olarak bulunmuştur $(45,46)$. Çalışmamızda KVY'li bireylerin depresyon düzeyleri incelendiğinde tedavi grubu lehine anlamlı azalma olduğu saptandı. Bu durum bize manyetik alan tedavisinin depresyon üzerinde olumlu etkisi olduğunu gösterdi. Bunun sebebinin KVY semptomlarının düzelmesi, ödemin azalmasıyla birlikte hastanın rahatlaması olduğunu düşünmekteyiz.

Sonuç olarak bu çalışma manyetik alan tedavisinin EHA, ödem ve depresyon üzerinde etkili olduğunu gösterdi. $\mathrm{Bu}$ araştırma manyetik alan tedavisinin KVY’nin venöz ülser oluşumundan önceki evrelerinde kullanıldığı ilk çalışmadır. Sekiz dakika gibi kısa bir tedavi süresinin olması ve yan etkisinin olmaması, portatif olması, evde bile kullanılabilmesi düşük frekanslı KEMA tedavisinin önemli avantajlarıdır.

Teknik yetersizliklerden dolayı mikrosirkülasyonun etkisinin direkt olarak değerlendirilmemesi çalışmamızın en önemli limitasyonlarındandır. Kısa dönemde KEMA tedavisi KVY'li bireylerin yaşam kalitesini artırmış olsa da uzun dönem sonuçları değerlendirilmedi. Tedavi grubundaki hastaların kompliyansı iyi olmasına rağmen kontrol grubundaki hastaların kompresyon çorabı kullanımı düzenli olarak takip edilemedi. Mikrosirkülasyonun da değerlendirildiği, uzun dönem takip yapılan daha büyük bir örneklemle çalışmanın tekrarlanmasının literatüre katkı sağlayacağı düşüncesindeyiz.

\section{AÇIKLAMALAR}

Bu çalışma Abant İzzet Baysal Üniversitesi Bilimsel Araştırma Projeleri birimi tarafından desteklenmiştir (Proje no: 2014.14.01.691).

\section{KAYNAKLAR}

1. Bergan JJ, Schmid-Schönbein GW, Smith PDC, Nicolaides AN, Boisseau MR, Eklof B. Chronic venous disease. N Engl J Med. 2006;355(5):488-98.

2. Callam M. Epidemiology of varicose veins. Br J Surg. 1994;81(2):167-73.

3. van Uden CJ, van der Vleuten CJ, Kooloos JG, Haenen J, Wollersheim H. Gait and calf muscle endurance in patients with chronic venous insufficiency. Clin Rehab. 2005;19(3):339-44.

4. Kunimoto B, Cooling M, Gulliver W, Houghton P, Orsted H, Sibbald RG. Best practices for the prevention and treatment of venous leg ulcers. J Wound Ostomy. 2001;47(2):34-51.

5. McKay JC, Prato FS, Thomas AW. A literature review: the effects of magnetic field exposure on blood flow and blood vessels in the microvasculature. Bioelectromagnetics. 2007;28(2):81-98.

6. Bohn W, Hess L, Burger R. The effects of the "physical BEMER $^{\circ}$ vascular therapy", a method for the physical stimulation of the vasomotion of precapillary microvessels in case of impaired microcirculation, on sleep, pain and quality of life of patients with different clinical pictures on the basis of three scientifically validated scales. J Complement Integr Med. 2013;10(Suppl):S5-S12.

7. Weiss RA, Munavalli G (ed.), Endovenous Ablation of Truncal Veins. Seminars in Cutaneous Medicine and Surgery. Elsevier: 2005.

8. Mariani F. Compression Consensus Document Based on Scientific Evidence and Clinical Experiences. Wounds International: 2015 .

9. Topal O. Ağız diş ve çene cerrahisinde darbeli elektromanyetik alan uygulamasının kemik iyileşmesi üzerine etkileri. SDÜ Sağ Bil Der. 2016;7(3):51-4.

10. Yalçin A, Saygin M. Elektromanyetik alanlarin üreme sistemi üzerine etkileri. Müh Bilim Tas Der. 2016;4(2):105-24.

11. Gümüşay M, Kaya A. Düşük Enerjili Darbeli Elektromagnetik Alanların Yara İyileștirmesine Etkileri Effects of Low Energy Pulsed Electromagnetic J Wound Heal.

12. Houghton P. Effects of therapeutic modalities on wound healing: a conservative approach to the management of chronic wounds. Phys Ther Rev. 1999;4(3):167-82.

13. Mayrovitz HN, Larsen PB. Effects of pulsed electromagnetic fields on skin microvascular blood perfusion. Wounds. 1992;4(5):197-202.

14. McMeeken JM. Magnetic fields: effects on blood flow in hu- 
man subjects. Physiother Theory Pract. 1992;8(1):3-9.

15. Santoro D, Ostrander L, Lee B, Cagir B, editors. Inductive 27.12 $\mathrm{MHz}$ diathermy in arterial peripheral vascular disease. Engineering in Medicine and Biology Society, 1994 Engineering Advances: New Opportunities for Biomedical Engineers Proceedings of the 16th Annual International Conference of the IEEE; 1994: IEEE.

16. Keith SL, McLaughlin DJ, Anderson FA, Cardullo PA, Jones $\mathrm{CE}$, Rohrer MJ ve ark. Do graduated compression stockings and pneumatic boots have an additive effect on the peak velocity of venous blood flow? Arch Surg. 1992;127(6):727-30.

17. Klyscz T, Jünger $M$, Schanz S, Janz M, Rassner G, Kohnen R. Quality of life in chronic venous insufficiency (CVI). Results of a study with the newly developed Tübingen Questionnaire for measuring quality of life of patients with chronic venous insufficiency. Der Hautarzt; Zeitschrift fur Dermatologie, Venerologie, und verwandte Gebiete. 1998;49(5):372-81.

18. Kurz X, Lamping DL, Kahn SR, Baccaglini U, Zuccarelli F, Spreafico $G$ ve ark. Do varicose veins affect quality of life? Results of an international population-based study. J Vas Surg. 2001;34(4):641-8.

19. Kaplan RM, Criqui MH, Denenberg JO, Bergan J, Fronek A. Quality of life in patients with chronic venous disease: San Diego population study. J Vas Surg. 2003;37(5):1047-53.

20. Smith JJ, Guest MG, Greenhalgh RM, Davies AH. Measuring the quality of life in patients with venous ulcers. J Vas Surg. 2000;31(4):642-9.

21. Garratt AM, Ruta DA, Abdalla MI, Buckingham JK, Russell IT. The SF36 health survey questionnaire: an outcome measure suitable for routine use within the NHS? BMJ. 1993;306(6890):1440-4.

22. Piatkowski J, Haase R, Ziemssen T. Long-term effects of bio-electromagnetic-energy-regulation therapy on fatigue in patients with multiple sclerosis. Altern Ther Health Med. 2011;17(6):22.

23. Piatkowski J, Kern S, Ziemssen T. Effect of BEMER magnetic field therapy on the level of fatigue in patients with multiple sclerosis: a randomized, double-blind controlled trial. J Altern Complement Med. 2009;15(5):507-11.

24. Özdemir ÖC, Tonga E, Tekindal A, Bakar Y. Cross-cultural adaptation, reliability and validity of the Turkish version of the Chronic Venous Disease Quality of Life Questionnaire (CIVIQ-20). SpringerPlus. 2016;5(1):381.

25. Kapci EG, Uslu R, Turkcapar H, Karaoglan A. Beck Depression Inventory II: evaluation of the psychometric properties and cut-off points in a Turkish adult population. Depression and Anxiety. 2008;25(10):E104-E10.

26. Otman SA. Tedavi Hareketlerinde Temal Değerlendirme Prensipleri, 4. ed. Ankara: Yücel Ofset; 2008.

27. Bérard A, Kurz X, Zuccarelli F, Abenhaim L. Validity of the Leg-O-Meter, an instrument to measure leg circumference. ANG. 2002;53(1):21-8.
28. Wollina U, Abdel-Naser MB, Mani R. A review of the microcirculation in skin in patients with chronic venous insufficiency: the problem and the evidence available for therapeutic options. Int J Low Extrem Wounds. 2006;5(3):169-80.

29. Shupak NM, McKay JC, Nielson WR, Rollman GB, Prato FS, Thomas AW. Exposure to a specific pulsed low-frequency magnetic field: a double-blind placebo-controlled study of effects on pain ratings in rheumatoid arthritis and fibromyalgia patients. Pain Res Manag. 2006;11(2):85-90.

30. Thomas AW, Graham K, Prato FS, McKay J, Forster PM, Moulin DE ve ark. A randomized, double-blind, placebocontrolled clinical trial using a low-frequency magnetic field in the treatment of musculoskeletal chronic pain. Pain Res Manag. 2007;12(4):249-58.

31. Haddad JB, Obolensky AG, Shinnick P. The biologic effects and the therapeutic mechanism of action of electric and electromagnetic field stimulation on bone and cartilage: new findings and a review of earlier work. J Altern Complement Med. 2007;13(5):485-90.

32. Ryaby JT. Clinical effects of electromagnetic and electric fields on fracture healing. Clin Orthop Relat Res. 1998;355:205-15.

33. Aziz Z, Cullum N, Flemming K. Electromagnetic therapy for treating venous leg ulcers. Cochrane Libr. 2013.

34. Athanasiou A, Karkambounas S, Batistatou A, Lykoudis E, Katsaraki A, Kartsiouni T ve ark. The effect of pulsed electromagnetic fields on secondary skin wound healing: an experimental study. Bioelectromagnetics. 2007;28(5):362-8.

35. Bohn W. The technological development history and current significance of the "physical BEMER ${ }^{\circledR}$ vascular therapy" in medicine. J Complement Integr Med. 2013;10(Suppl):S1S3.

36. Selvam R, Ganesan K, Raju KN, Gangadharan AC, Manohar BM, Puvanakrishnan R. Low frequency and low intensity pulsed electromagnetic field exerts its antiinflammatory effect through restoration of plasma membrane calcium ATPase activity. Life Sci J. 2007;80(26):2403-10.

37. Miller BF, Gruben KG, Morgan BJ. Circulatory responses to voluntary and electrically induced muscle contractions in humans. Phys Ther. 2000;80(1):53.

38. Back TL, Padberg FT, Araki CT, Thompson PN, Hobson RW. Limited range of motion is a significant factor in venous ulceration. J Vasc Surg. 1995;22(5):519-23.

39. Yang D, Vandongen Y, Stacey M. Effect of exercise on calf muscle pump function in patients with chronic venous disease. J Brit Surg. 1999;86(3):338-41.

40. Desjardins C, Duling BR. Heparinase treatment suggests a role for the endothelial cell glycocalyx in regulation of capillary hematocrit. Am J Physiol Heart Circ Physiol. 1990;258(3):H647-H54.

41. Guex J, Perrin M. Edema and leg volume: methods of assessment. ANG. 2000;51(1):9-12.

42. Vanhoutte P, Corcaud S, De Montrion C, Vanhoutte PM. 
Venous disease: from pathophysiology to quality of life. ANG. 1997;48(7):559-67.

43. Andreozzi G, Cordova R, Scomparin M, Martini R. Effects of elastic stocking on quality of life of patients with chronic venous insufficiency: an Italian pilot study on Triveneto Region. Int Angiol. 2005;24(4):325.

44. Abenhaim L, Kurz X. The VEINES study (VEnous Insufficiency Epidemiologic and Economic Study): an international cohort study on chronic venous disorders of the leg. ANG. 1997;48(1):59-66.

45. Salomé GM, Blanes L, Ferreira LM. Evaluation of depressive symptoms in patients with venous ulcers. Plast Reconstr Surg. 2012;27(1):124-9.

46. Palfreyman S, Michaels J. A systematic review of compression hosiery for uncomplicated varicose veins. Phlebology. 2009;24(1_suppl):13-33. 